\title{
DETECTION OF PROTEINS AS ORGANIC ADDITIVE IN FLOORING MORTARS USED IN EXCAVATED REMAINS FROM ANBA SHENOUTE MONASTERY, SOHAG, EGYPT
}

\author{
Amr Osman \\ Department of Conservation, Faculty of Archaeology, Sohag University, Egypt \\ E.mail: amr_osman@art.sohag.edu.eg
}

\begin{abstract}
Detecting organic additives in ancient mortars is significant to be carried out as far as mineralogical, chemical, and physical investigations. That characterisation allows understanding the technology of those mortars and is important to make appropriate decisions in conservation works. Previous characterisations of organic additives in mortars, including jointing and flooring ones used in the Red Monastery located next to Anba Shenoute monastery, have shown the presence of proteins in flooring mortars specifically. This study aims to confirm the addition of protein-based materials in flooring mortars in Anba Shenoute Monastery which almost dated back to the same period $\left(4^{\text {th }}-6^{\text {th }}\right.$ century AD). Samples were taken from different flooring mortars and underwent wet chemical analysis, using Comassie Brilliant blue test. Results confirm the addition of proteinaceous additives, raising the probability of intended use for enhancing properties of flooring mortars.
\end{abstract}

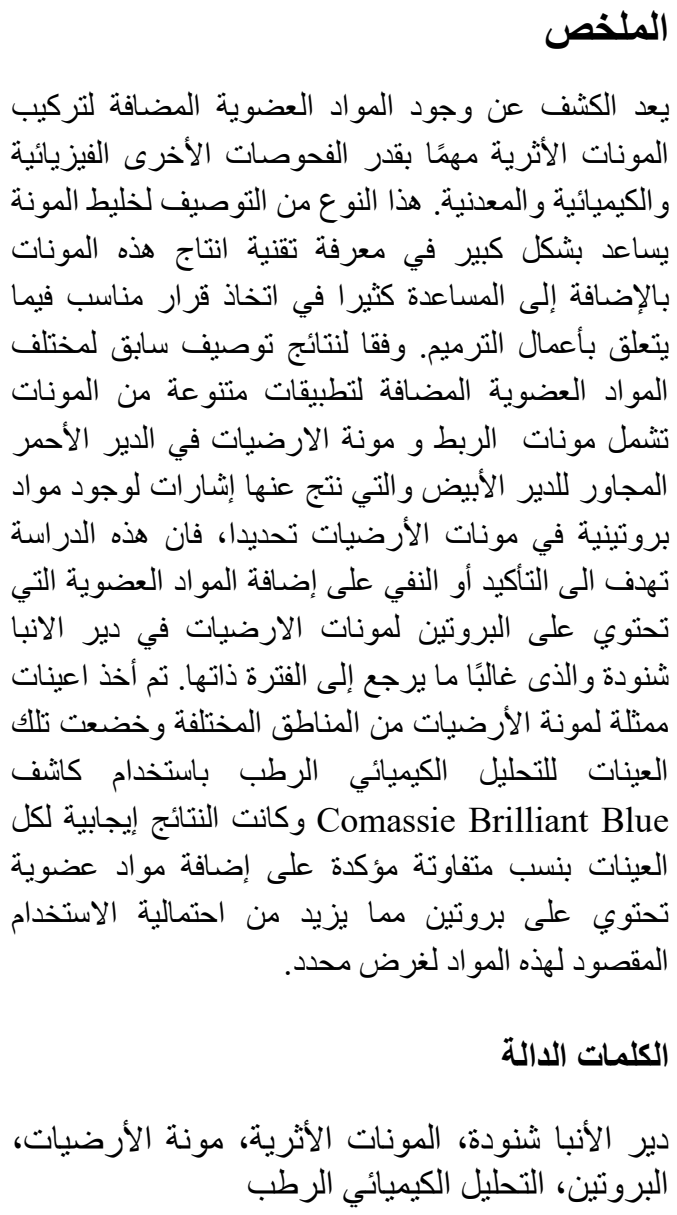

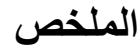
دير الأنبا شنودة، المونات الأثرية، مونة الأرضيات، البروتين، التحليل الكيميائي الرطب الآنبة صودي

Anba Shenoute Monastery, Ancient mortars, Flooring mortars, Protein, wet chemical analysis 


\section{INTRODUCTION}

Organic additives play an important role in enhancing properties of mortar mixture including aggregates and binders. Organic additives were added to lime mortars ${ }^{1}$ in order to improve their workability and strength. Some remain solid and visible, such as straw, dung, hair, etc. Other substances containing protein are more difficult to be detected, being liquid such as milk, eggs and glue, as well as a variety of carbohydrates including sugar, gums, honey, bark extracts, blood, cheese, casein, saffron and beeswax. ${ }^{2,3}$ Each additive had a certain consequence on the mortars. Adding sugar, for instance, increases the solubility of calcium hydroxide in water in case of lime putty. Moreover, added sugar delays the setting time allowing the formation of a denser crystal structure. ${ }^{4}$ On the other hand, adding protein leads to intensive air entraining, which affects the physical properties of both fresh mortar (consistence, plasticity, volumetric density) and hardened mortar (bending strength, shrinkage, volumetric density and frost resistance). ${ }^{5}$ The effects of adding other organic additives, such as honey and the juice form local plants in Mesoamerica, ${ }^{6}$ are still debated. Detecting and characterising the organic materials added to ancient mortars helps to understand better the technology of those mortars in terms of composition and binder type, ${ }^{7}$ as well as to enable informed choices with regards to the materials for designing repair mortars required for restoration works. ${ }^{8}$

In the context of a thorough characterisation of the historic mortars of Anba Shenoute Monastery including their mineralogical, chemical and physical properties, this study focuses on organic additives which might be present in the composition of these flooring mortars, dating to the $4^{\text {th }}-6^{\text {th }}$ century AD in Egypt. ${ }^{9,10}$ Flooring mortars have been selected to confirm or deny the results of previous similar analyses done on flooring mortar from Anba Bishoi Monastery, a site located $3.6 \mathrm{Km}$ to the north. ${ }^{11}$ It has been carried out to identify organic additives including sugar, starch, blood, and glycerides (fatty acids). The results of the present study widen our understanding of the technology and the composition of those mortars, facilitating appropriate decisions during restoration.

\section{HISTORICAL BACKGROUND}

Anba Shenoute Monastery is located in Sohag governorate, about $500 \mathrm{~km}$ to the south of Cairo, on the west bank of the Nile. This site is also known by the population as Dayr alAbiad, the White Monastery, as its church was built with white limestone. ${ }^{12}$ This church dates to the second half of the $4^{\text {th }}$ century ${ }^{13}$ and was studied at the end of the $19^{\text {th }}$ century by

\footnotetext{
${ }^{1}$ Hayen, et.al, The influence.p. 2

${ }^{2}$ Hansen, Ancient Maya Burnt-lime, P.67,68

${ }^{3}$ Sickels, Mortars in old buildings, p.47

${ }^{4}$ Hansen, op. cit., p. 68

${ }^{5}$ Jasiczak, \& Zielinski, Effect of protein additive, p 451.

${ }^{6}$ Artioli, G. et al, The Vitruvian legacy, p.152

${ }^{7}$ Moropoulou, A. et.al., Investigación of the technology of historic mortars, p. 45,57

${ }^{8}$ Veiga, M. R. et al.: Methodologies for characterisation.p.356

${ }^{9}$ Bolman, "Late Antique, p. 6

${ }^{10}$ Mofida et al, "Early Wall Paintings , p. 49

${ }^{11}$ Osman, A. Characterization of historical mortars, P. 199

${ }^{12}$ Bolman, Late Antique Aesthetics, p. 1-24;

${ }^{13}$ Bolman, Late Antique, op.cit,p.6.
}

- 204 - Detection of proteins as organic additive in flooring mortars 
A.J. Butler ${ }^{14}$ and then, at the beginning of the $20^{\text {th }}$ century, described and photographed by De Villard. ${ }^{15}$

The Committee for the Conservation of Arab Antiquities planed and estimated a budget to do some restoration works in 1909 , which may be carried out later ${ }^{16}$. At the end of the $20^{\text {th }}$ century, excavation and restoration works took place in the White Monastery by the Egyptian Supreme Council of Antiquities (SCA) and different foreign archaeological missions. ${ }^{17,18,19}$

\section{MATERIALS AND METHODS}

12 samples were extracted from two areas containing lime flooring mortars using a hammer and chisel; first, Area 1 - Unit $O$ illustrating a large multi-room building, containing plastered cisterns and a kiln, and Area 2 - Unit $Q$, an open floor courtyard and food production installations. Visually, all samples are composed of two different layers. Mortar samples numbers and their locations are presented in Table 1. In order to identify the invisible organic additives, the new methodology developed by Fang et al. $2014^{20}$ has been applied, by using chemical reagents (wet chemical analysis) to detect the presence of organic additives such as protein, sugar, starch, blood, and glycerides (fatty acids). This method was used on ancient Chinese traditional lime mortars, which contain such organic additives. $^{21}$

In my present work, Coomassie brilliant blue ${ }^{22}$, the reagent proposed by Fang and his team to detect the presence of proteins in lime mortars, was applied to my samples, as seen in Figures 10 and 11. At first, the chemical reagent was prepared according to the specific procedure developed by FANG et.al. 2014: $100 \mathrm{mg}$ of Coomassie brilliant blue G250 dissolved in $50 \mathrm{ml} \mathrm{95 \%} \mathrm{ethanol;} 100 \mathrm{ml}$ of $85 \%$ phosphoric acid and distilled water were added to reach $1000 \mathrm{ml}$. This solution was filtered and kept at $4^{\circ} \mathrm{C}$. The samples were prepared in a way that $0.1 \mathrm{~g}$ of the powdered bulk sample was dissolved in $1 \mathrm{~mol} / \mathrm{l} \mathrm{HCl}$, then its $\mathrm{pH}$ to 5-6 adjusted. Once solutions were ready, $1 \mathrm{ml}$ of solution of each sample was added to $1 \mathrm{ml}$ of Coomassie brilliant blue. The reaction turned the colour blue in the presence of proteins. That procedure was applied to both upper layers and lower layer of the 12 samples.

Table 1. Samples from the Monastery of Anba Shenoute, and their locations.

\begin{tabular}{|c|c|}
\hline Bulk Sample No. & Location \\
\hline WM1, WM2, WM3, WM4, WM5, WM6 & Area 1 - unit O \\
\hline WM7, WM8, WM9, WM10, WM11, WM12 & Area 2 - unit Q \\
\hline
\end{tabular}

\footnotetext{
${ }^{14}$ Butler, The Ancient Coptic, vol.1, p. 357.

${ }^{15}$ De Villard, Les couvents près de Sohâg,

${ }^{16}$ Bulletins de Comité de Conservation des Monuments de l'Art Arabe 1909, P. 116.

${ }^{17}$ Bolman, The Red Monastery, p. 261 - 281.

${ }^{18}$ Mori, "Convento Rosso" visto da "occidente", p. 129

${ }^{19}$ Bolman, Shenoute and a Recently Discovered Tomb. P.453

${ }^{20}$ Fang, S. et al, The identification, p.144-150.

${ }^{21}$ Fang, S. et al, The identification, p.144-150

${ }^{22}$ Fang, S. et al, op. cit., p. 146.
} 


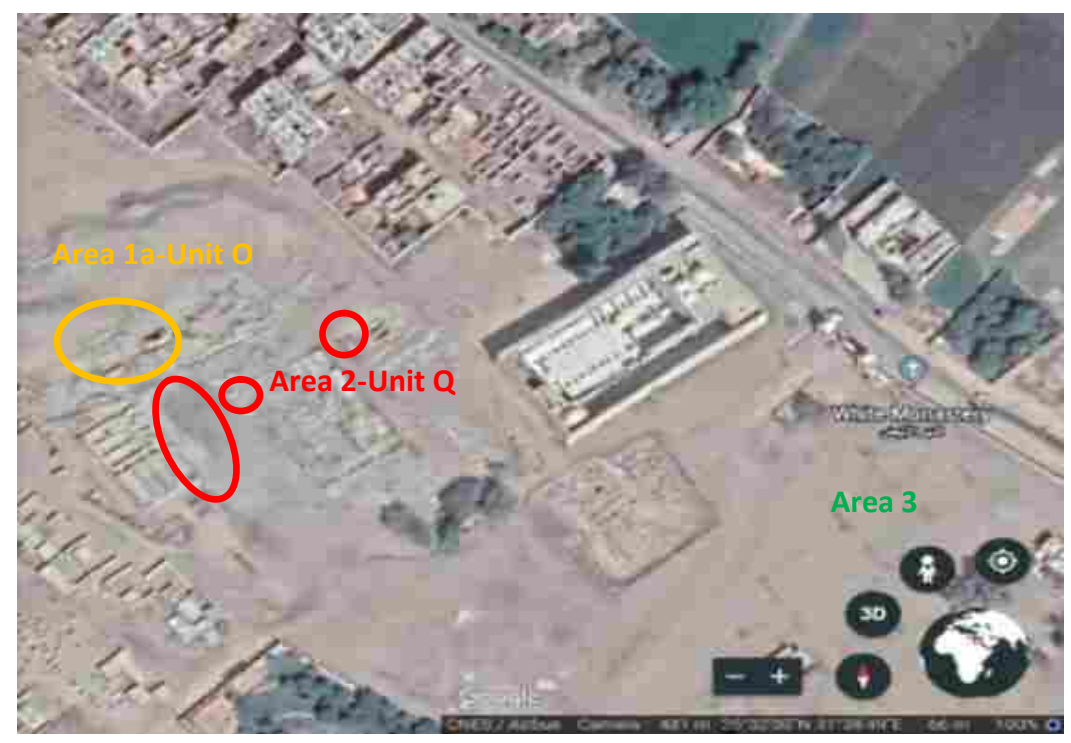

Fig.1 Satellite view of the White Monastery area via Google Earth illustrating area 1 - unit $O$ and area 2 - unit $Q$ (taken on 24.April. 2019)

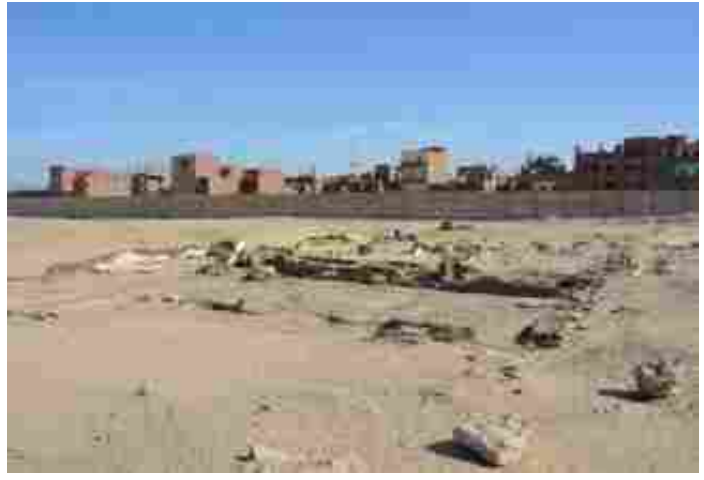

Fig. 2 Multiroom building area

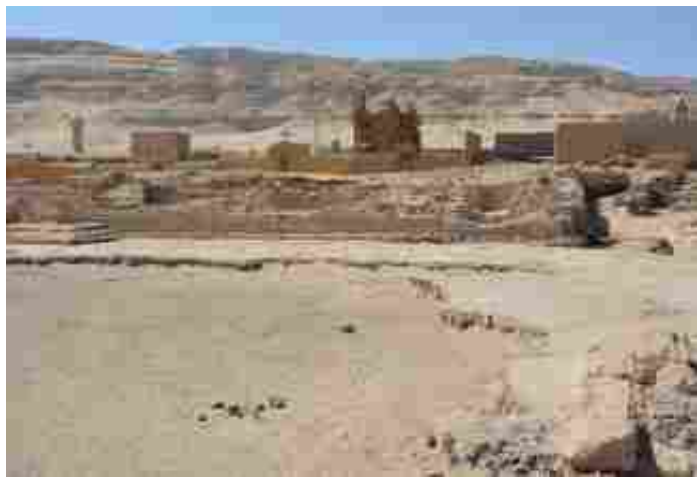

Fig.4 Flooring mortar from open-air courtyard

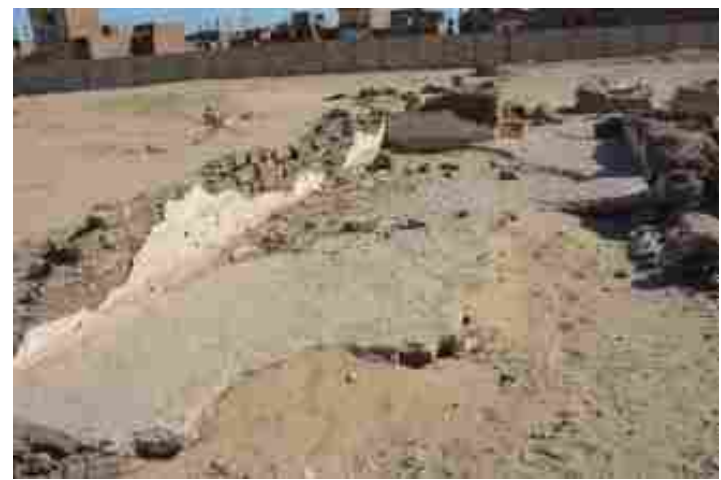

Fig.3 Flooring mortar of the multiroom building

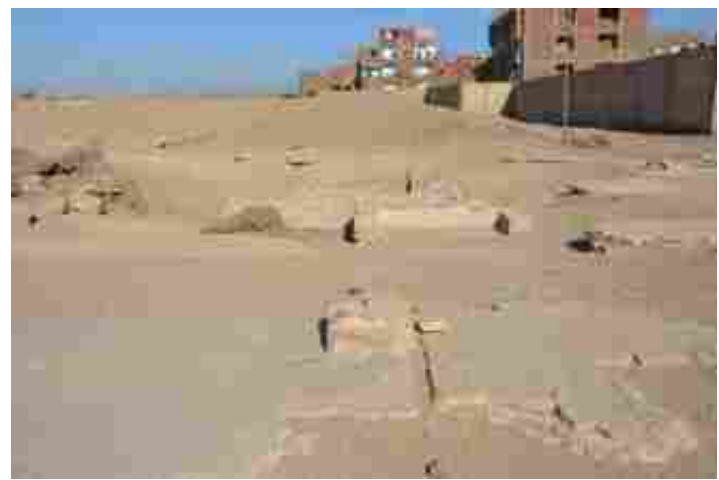

Fig.5 Flooring mortar from food production area 

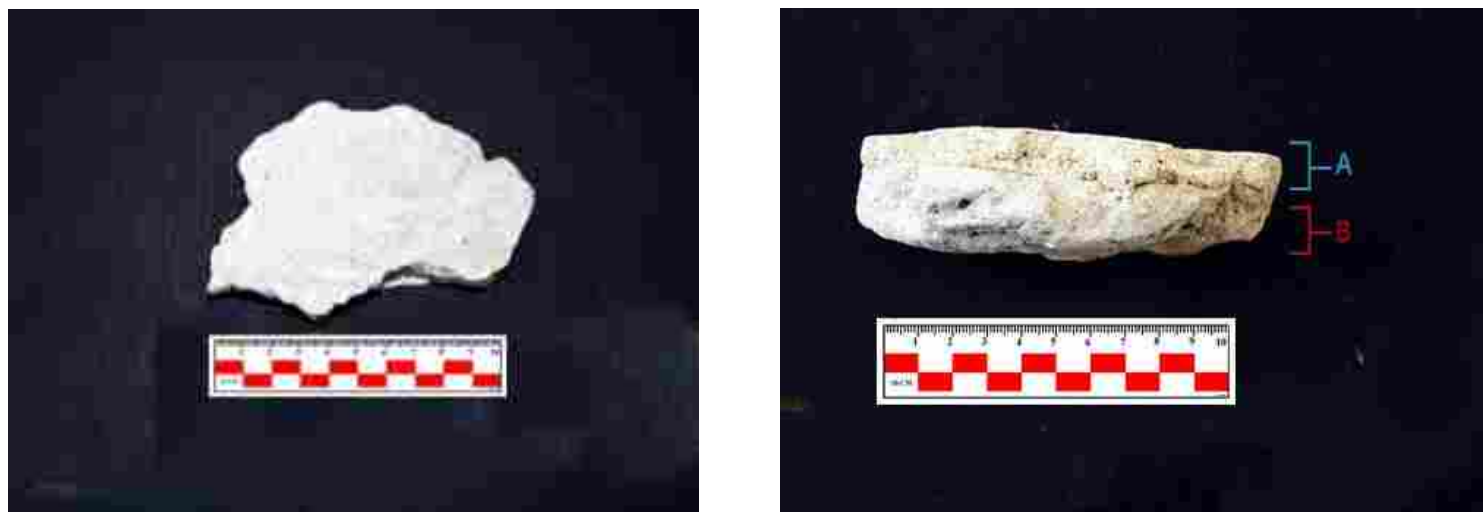

Fig.6 Flooring mortar sample WM1

Fig.7 Two layers of the flooring mortar sample WM8
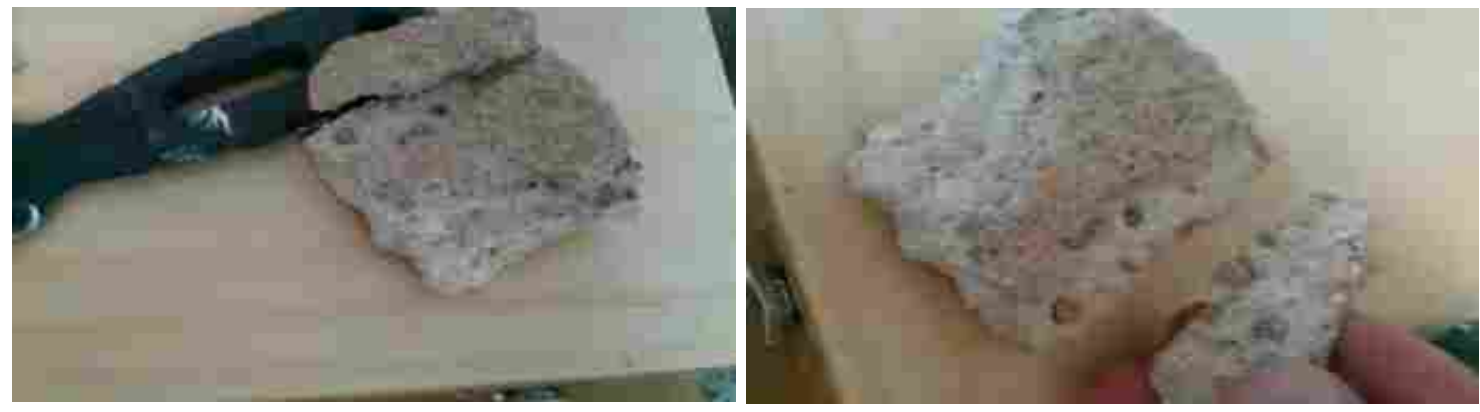

Figs. 8 and 9 Separation of layers manually using a chisel and hammer
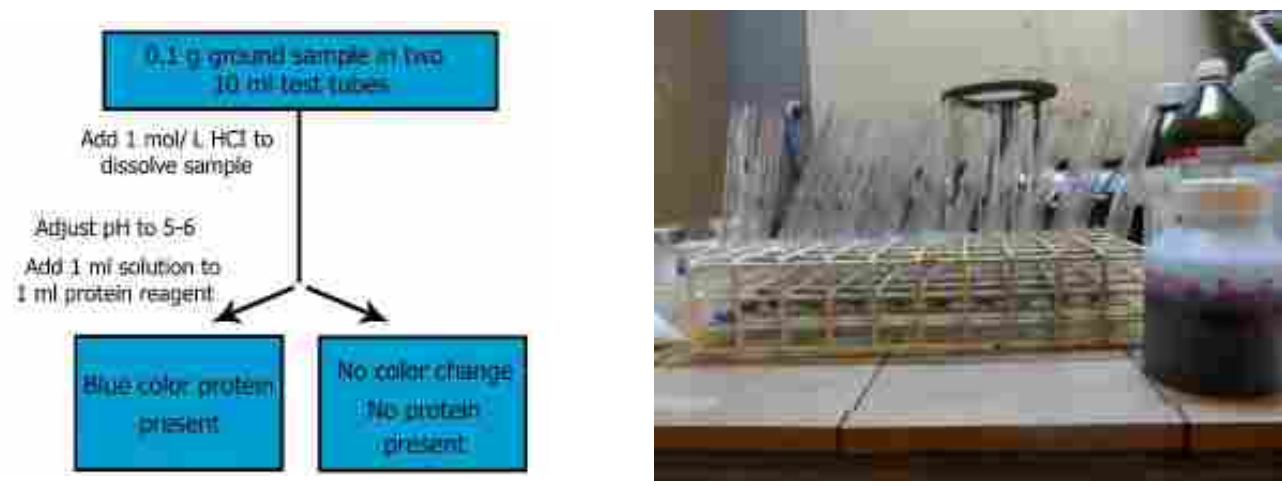

Fig.10. Scheme of classical chemical analysis for detection of protein

Fig.11. Testing procedures in the laboratory 


\section{RESULTS AND DISCUSSION}

Samples WM1, WM2, WM3, WM4, WM5, WM6 from the Multiroom building in Area 1Unit O as well as Samples WM7, WM8, WM9, WM10, WM11, WM12 from the Central plastered open floor and food production installations in Area 2 - Unit Q manifested a blue colouring through wet chemical analysis using Coomassie brilliant blue testing, revealing the presence of protein, in various proportions, as indicated by the intensity of the resulting blue. Those results were positive for both the upper layers and the lower layers of samples (WM1-WM12) as shown in figures 12a,12b, 13a and 13b respectively.

Variations found in the obtained blue colour indicate the remaining quantity of proteins in the mortar. The detection of positive signs in tested flooring mortars from different locations gives an indication of intentional using of organic additives to improve the quality of flooring mortars and to permit intensive air entraining. It leads to a final product that is hardened, resistant and long lasting. In addition, it is clear that such proteins were voluntarily added to the mortars, since positive signs were also detected in the lower layer, denying that coincidental remnants proteinaceous materials were on the surface, resulted from possible industrial activity such as oil, food, etc.
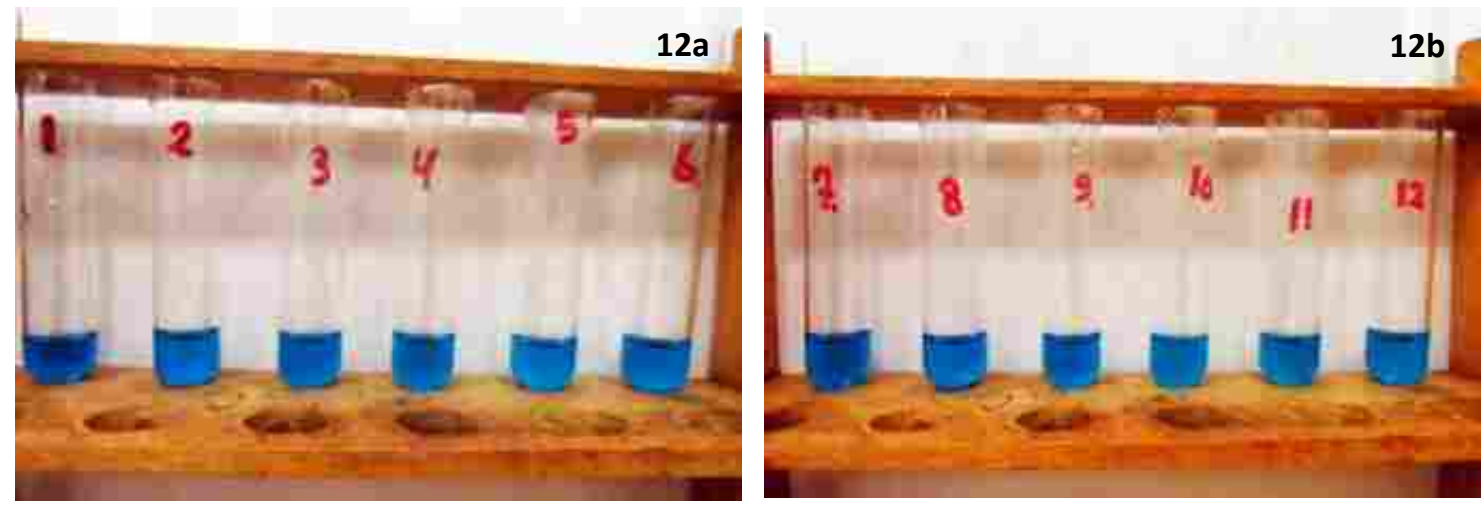

Fig. 12a and 12b Results of chemical analysis by protein reagent for the upper layers of samples WM1-WM6 (Fig.12a) and WM7 - WM12 (Fig.12b) respectively
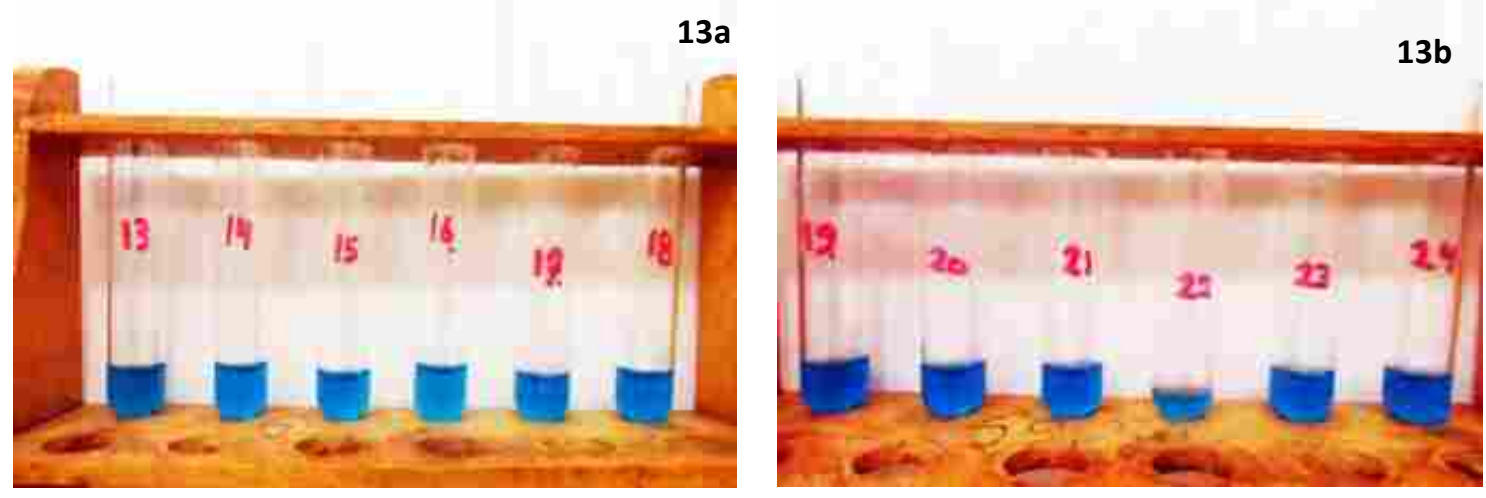

Fig. 13a and 13b Results of chemical analysis by protein reagent for the lower layers of samples WM1-WM6 (Fig.13a) and WM7 - WM12 (Fig.13b) respectively

- 208 - Detection of proteins as organic additive in flooring mortars 


\section{CONCLUSIONS}

This study confirmed the presence of proteinaceous materials added to flooring mortars as an organic additive to improve their properties in Anba Shenoute Monastery. That supports the use of protein based additives which were already found in flooring mortars used in Anba Bishoi Monastery. Accordingly, it underlines that this specific technology of adding organic additives to mortars, was clearly known in Coptic architecture. The awareness of such presence of organic additives leads to further questions related to the origin of that protein, an estimation of its quantity, using more chemical and sophisticated instrumental methods such as Fourier-transform infrared spectroscopy (FTIR), liquid chromatography (LC) and amino acid analyzer. Furthermore, when identifying the proteins' origins, they or modern materials with similar properties can be candidates as additives - after being evaluated- for designing repair mortars for conservation process to achieve compatibility with original archaeological mortars. Finally, this site of the White monastery still requires more studies with regards to the building materials used and their construction's phases in general, and mortar types and their compositions specifically. 


\section{REFERENCES}

- Artioli (G.), Secco (M.) and Addis (A.), The Vitruvian legacy: mortars and binders before and after the Roman world, EMU Notes in Mineralogy, Vol. 20 (2019), Chapter 4, 151202.

- Bolman (E. S.), The Red Monastery Conservation Project, 2004 Campaign: New Contributions to the Corpus of Late Antique Art, (2007), p. 261 - 281.

- Bolman (Elizabeth S.), Late Antique Aesthetics, Chromophobia, and the Red Monastery, Sohag, Egypt, ECA 3 (2006), p. 1-24;

- Bolman, E. Blanke, L. Brooks Hedstrom, D. Khalifa, M. Meurice, C. Mohammed, S. Pyke, G. and Sheehan, P. Late Antique and Medieval Painted Decoration at the White Monastery (Dayr al-Abiad), Sohag," Bulletin of the American Research Center in Egypt ARCE, 192 (2007): 5- 11.

- Bulletins of the Comité de Conservation des Monuments de l'Art Arabe 1909, translated by Ali Bek Bahgat, Matba3a Diwan 3mom Al awkaf, 1913.

- Butler (A. J.), The Ancient Coptic Churches of Egypt, vol.1, Clarendon press, 1884

- De Villard (U. M), Les couvents près de Sohâg (Deyr el-Abiạ̣ et Deyr el-Aḥmar), Imprimé par la Tipografia Pontif, Arciv. S. Giuseppe, Vol. 2, 1926

- $\quad$ Elert (K.), Rodriguez-Navarro (C.), Pardo (E.S.), Hansen (E.), Cazalla (O.), Lime mortars for the conservation of historic buildings, Studies in Conservation. 47, No.1 (2002) 62-75.

- Fang, (S. Q.), Zhang, (H.), Zhang, (B. J.), \& Zheng, (Y.), The identification of organic additives in traditional lime mortar. Journal of Cultural Heritage, 2014, 15(2), 144-150.

- Hansen (E. F.), Ancient Maya Burnt-lime Technology: Cultural Implications of Technological Styles, University of California, Los Angeles, 2000

- Hayen (R.), Van Balen (K.), \& Van Gemert (D.), The influence of production processes and mortar compositions on the properties of historical mortars. In $9{ }^{\text {th }}$ Canadian Masonry Symposium - Spanning the Centuries with Masonry, New Brunswick. 2001

- Hedstrom (Darlene L. Brooks), Bolman (Elizabeth S.), Abdel Rahim (Mohammed), Mohammed (Saad), McCormack (Dawn), Herbich (Tomasz), Pyke (Gillian), Blanke (Louise), Musacchio (Tracy), Khalifa (Mohammed), The White Monastery Federation Project Survey and Mapping at the Monastery of Apa Shenoute (Dayr al-Anba Shinūda), Sohag, 2005-2007, Dumbarton Oaks Papers Volumes 65 and 66 | 2011-2012, pp.333-371.

- $\quad$ https://earth.google.com/web/@,26.53445963,31.64533618,67.88132308a,413.29307813d,3 5y,1.03923168h,0t,0r (Visited on 24April 2019)

- Jasiczak (J.), \& Zielinski (K.), Effect of protein additive on properties of mortar. Cement and Concrete Composites, 2006, 28(5), 451-457.

- Middendorf, (B.), Hughes, (J.J.), Callebaut, (K.), Baronio, (G.), Papayianni, (I.), 2005b. Investigative methods for the characterisation of historic mortars - Part 2: chemical characterisation. Materials and Structures, 38, pp.771-780

- Middendorf, (B.), Hughes, (J.J.), Callebaut, (K.), Baronio, (G.), Papayianni, (I.), 2005a. Investigative methods for the characterisation of historic mortars - Part 1: mineralogical characterisation. Materials and Structures, 38, pp.761-769

- Mori (D. F.), "Convento Rosso" visto da "occidente": fonti documentarie e iconografiche dal XVII secolo ad oggi utili per una storia conservativa del monumento, in: F. Severini (ed.), Progetto pilota Deir el Ahmar, Deir Anba Bishoi "Convento Rosso", Roma 2004, p. 129 - 136.

\footnotetext{
- 210 - Detection of proteins as organic additive in flooring mortars
} 
- Moropoulou (A.), Bakolas (A.), Bisbikou (K.), Investigation of the technology of historic mortars, Journal of Cultural Heritage 1 (2000) 45-58.

- Osman, (Amr), Characterization of historical mortars from chosen byzantine sites in Egypt with conservation recommendations, Doctoral thesis, Faculty of Architecture, Wrocław University of Technology, 2015.

- Rodriguez-Navarro (C.), Hansen (E.), Ginell (W.S.), Calcium hydroxide crystal evolution upon aging of lime putty, Journal of american Ceramic Society, 81 (1998) 3032-3034.

- Sickels (L.B.), Mortars in old buildings and masonry conservation: A historical and practical treatise (Doctoral dissertation, University of Edinburgh), 1988.

- Veiga (M. R.), Aguiar (J.), Silva (A. S.) and Carvalho (F.), Methodologies for characterisation and repair of mortars of ancient buildings, in Proc. International Seminar of Historical Constructions P.B. Lourenço, P. Roca (Eds.),, Guimarães, Portugal, Universidade do Minho, 2001, pp.353-362.

- Weshahy (Mofida Hassan), Kadous (Ezzat Zaki), Alpasuoni (Khaled Shouky), Halim (Sara Maher), Early Wall Paintings for Jesus Christ Represented in the Red Monastery, International Journal of Heritage, Tourism and Hospitality Vol. (12), No. (3/2)Special issue on papers of the 11thICTH (2018) organized by Faculty of Tourism and Hotels, Fayoum University, pp. 48-58

- Zhaoa (Peng), Jacksonb (Marie D.), Zhanga (Yunsheng), Lic (Guangyan), J.M. (Paulo), Lin Yang (Monteirob), Material characteristics of ancient Chinese lime binder and experimental reproductions with organic admixtures, Construction and Building Materials, 2015,84: 477-488. 